\title{
Regulatory Policy and the Social Sciences
}


California Series on

Social Choice and Political Economy

Edited by Brian Barry and Samuel L. Popkin 


\title{
Regulatory
}

Policy and

the Social

Sciences

\author{
Edited by \\ Roger G. Noll
}

UNIVERSITY OF CALIFORNIA PRESS Berkeley LosAngeles London 
University of California Press

Berkeley and Los Angeles, California

University of California Press, Ltd.

London, England

- 1985 by

The Regents of the University of California

Library of Congress Cataloging-in-Publication Data

Main entry under title:

Regulatory policy and the social sciences.

Based on papers presented at the Conference on Regulation and the Social Sciences, held at Reston, Va., Jan. 1982, and sponsored by the National Science Foundation's Regulation and Policy Analysis Program.

Bibliography: p.

1. Trade regulation- United States-Congresses. 2. Social sciences-Research-United States-Congresses. I. Noll, Roger G. II. Conference on Regulation and the Social Sciences (1982: Reston, Va.) III. Regulation and Policy Analysis Program (National Science Foundation) HD3616.U47R144 $1985 \quad 338.973 \quad 85-16515$ ISBN 0-520-05187-4 (alk. paper)

Printed in the United States of America

$\begin{array}{lllllllll}1 & 2 & 3 & 4 & 5 & 6 & 7 & 8 & 9\end{array}$ 